\title{
Reproduction, growth and connectivity among populations of Girella tricuspidata (Pisces: Girellidae)
}

\author{
C. A. Gray ${ }^{1,2, *}$, J. A. Haddy ${ }^{1,3}$, J. Fearman ${ }^{1,3}$, L. M. Barnes ${ }^{1,4}$, W. G. Macbeth ${ }^{1}$, \\ B. W. Kendall ${ }^{1}$ \\ ${ }^{1}$ Cronulla Fisheries Research Centre, PO Box 21, Cronulla, New South Wales 2230, Australia \\ ${ }^{2}$ Biological, Earth \& Environmental Sciences, University of New South Wales, New South Wales 2052, Australia \\ ${ }^{3}$ Australian Maritime College, University of Tasmania, Tasmania 7250, Australia \\ ${ }^{4}$ Biological Sciences, Macquarie University, New South Wales 2113, Australia
}

\begin{abstract}
Girella tricuspidata is widely distributed and harvested by recreational and commercial fishers along the coastline of eastern Australia. The present study examined variability in the reproductive biology and growth of individuals within populations of G. tricuspidata across 3 estuaries (Clarence, Tuggerah and Tuross) and assessed population connectivity via a large-scale tagrecapture study in which fish were tagged across 9 estuaries. Spawning occurred predominantly between June and September in the Clarence River and between October and January in the Tuross River, suggesting that spawning occurs later in the year at higher latitudes. The recruitment of young to nursery grounds was spatially and temporally variable. G. tricuspidata are group-synchronous spawners, and the estimated batch fecundity was positively correlated with fish length. The estimated length and age at which $50 \%$ of G. tricuspidata attained reproductive maturity was similar for both sexes: $286 \mathrm{~mm}$ fork length (FL) and $4.1 \mathrm{yr}$ for males and $295 \mathrm{~mm}$ FL and $4.5 \mathrm{yr}$ for females. G. tricuspidata were aged using otoliths to $>26 \mathrm{yr}$, whereas the reading of scales consistently underestimated the age of fish older than 5 yr. Growth was flexible but varied significantly between sexes and among estuaries; females grew faster than males and attained a larger asymptotic length in the Clarence and Tuross Rivers but not in Tuggerah Lake. Growth was rapid for both sexes until 4 to $5 \mathrm{yr}$ of age, after which it slowed. Of the 6871 G. tricuspidata tagged, $15 \%$ were recaptured, with $96 \%$ of these fish recaptured in the estuary in which they were initially tagged. The recaptured individuals that migrated between estuaries predominantly displayed a northward movement into the prevailing coastal current, which is probably a life-history tactic to facilitate wide dispersal of eggs and larvae along eastern Australia.
\end{abstract}

KEY WORDS: Fish · Life history · Maturity · Spawning · Otolith · Ageing · Movement · Tag • Australia Resale or republication not permitted without written consent of the publisher

\section{INTRODUCTION}

Members of the teleost family Girellidae occur in shallow coastal and estuarine subtropical and temperate waters of the Pacific, Indian and Atlantic Oceans (Yagishita \& Nakabo 2000, www.fishbase.org). The family comprises 18 species of Girella and the monotypic Graus. There is little widely published documen- tation of the fundamental life-history characteristics of the Girellidae, including reproductive mode, size and age at maturity, growth, longevity and mortality schedules. Such information is important for advancing our understanding of the population ecology and ecological role of these fishes and assisting in management for sustainable fisheries exploitation (Megrey 1989, Campana 2001, Begg et al. 2005, Ruttenberg et al. 2005). 
Girella tricuspidata inhabits estuaries and nearshore coastal waters along eastern and southern Australia and around the north island of New Zealand (Kailola et al. 1993, Miskiewicz \& Trnski 1998), where it is a significant component of several recreational and commercial fisheries (West \& Gordon 1994, Gray \& Kennelly 2003, Gray et al. 2005, 2010, Butcher et al. 2011). In New South Wales (NSW) alone, 700 to $1000 \mathrm{t}$ of $G$. tricuspidata are harvested in total by recreational and commercial anglers each year (Henry \& Lyle 2003, Rowling et al. 2011). These fish can live for $>25$ yr but may be subject to high rates of fishing mortality that can vary spatially and temporally (Gray et al. 2010). At present, broad-scale management arrangements apply to the commercial and recreational fishing sectors and include fishing gear restrictions, minimum legal lengths (MLL) of fish that can be retained $(270 \mathrm{~mm}$ total length [TL], $\sim 250 \mathrm{~mm}$ fork length [FL] in NSW) and recreational possession limits (20 individuals in NSW). These management initiatives were developed in the absence of information concerning the species reproductive biology, knowledge of which could help develop more appropriate management plans for the species (Jakobsen et al. 2009). Further, many of the estuaries in which $G$. tricuspidata occur in eastern Australia have different fishing management regimes (e.g. open or closed to commercial fishing, recreational only or marine reserve), and there is an increasing need to understand the effects of these differing management regimes on exploited populations. This requires an understanding of the linkages and connectivity of populations among these different estuaries (Meyer et al. 2007, Chateau \& Wantiez 2009).

Fish display flexible life-history characteristics that can vary throughout their distribution (Meekan et al. 2001, Ruttenberg et al. 2005) and, for some species, among individual estuaries within a specific region (Sarre \& Potter 1999, Bedee et al. 2002). In the present study, we examine aspects of the reproductive biology and growth of Girella tricuspidata across 3 estuaries in eastern Australia. We specifically investigate the time of reproductive activity, length and age at sexual maturity, mode of oocyte development and potential batch fecundity, and test for differences in growth parameters between sexes and among populations. We also build on previous otolith-based ageing work (Gray et al. 2010) by examining the timing when the first opaque growth zone on otoliths is deposited. The large-scale movements and population connectivity of $G$. tricuspidata among estuaries was investigated through a tag-recapture study. We discuss the life-history characteristics of G. tricuspi- data in relation to current knowledge of the ecology and management plans for the species.

\section{MATERIALS AND METHODS}

\section{Sampling}

Girella tricuspidata were sampled from the Clarence River $\left(29.427^{\circ} \mathrm{S}, 153.372^{\circ} \mathrm{E}\right)$, Tuggerah Lake $\left(33.345^{\circ} \mathrm{S}, 151.504^{\circ} \mathrm{E}\right)$ and the Tuross River $\left(36.067^{\circ} \mathrm{S}, 150.135^{\circ} \mathrm{E}\right)$ in NSW, Australia, at regular intervals (generally monthly) between September 2003 and March 2005. Fish from the Clarence River and Tuggerah Lake were obtained mainly from commercial gillnet (80 to $100 \mathrm{~mm}$ stretched mesh) catches, whereas fish from the Tuross River were collected from research multi-mesh gillnets with 50 to $100 \mathrm{~mm}$ stretched mesh and a $140 \mathrm{~m}$ beach-seine with $25 \mathrm{~mm}$ mesh. A total of $2571 \mathrm{G}$. tricuspidata were collected for reproduction and age examination. The FL (mm), total weight $(0.1 \mathrm{~g})$ and sex were determined for each fish sampled.

\section{Reproductive staging and activity}

Gonads were removed, weighed (0.1 g), macroscopically examined and assigned a reproductive stage according to a developmental criteria based on the size, colour and visibility of oocytes (adapted from Scott \& Pankhurst 1992) (Table 1). Female and male Stages I and II were considered immature, female Stages III to V and male Stages III to IV were considered mature, and female Stage VI and male Stage V were spent. The macroscopic staging of females was validated by microscopic examination of a small subset of individuals: Stage II immature ovaries contained unyolked oocytes of a variety of sizes; Stage III ovaries contained a mixture of unyolked, partially yolked and advanced yolk stage oocytes; Stage IV ovaries contained hydrated oocytes and oocytes in each of the previous stages of development.

The timing of reproductive activity at each location was assessed by examining trends in the peaks and troughs in the mean male and female gonadosomatic indices (GSI) and proportions of macroscopic gonad stages among months. GSI were calculated for all mature fish: GSI $=\left(\mathrm{W}_{\mathrm{G}} / \mathrm{W}_{\mathrm{T}}\right) \times 100$, where $\mathrm{W}_{\mathrm{G}}$ is the gonad weight, and $\mathrm{W}_{\mathrm{T}}$ is the total weight of the fish. This index is commonly used in fish reproduction studies; however, we acknowledge its potential limitations as discussed by Ebert et al. (2011). 
Table 1. Macroscopic appearance and corresponding histological condition used to stage gonads and testes of Girella tricuspidata. Adapted from Scott \& Pankhurst (1992)

\begin{tabular}{|c|c|c|c|}
\hline Stage & Classification & Macroscopic appearance & Histological characteristics \\
\hline \multicolumn{4}{|c|}{ Female } \\
\hline I & Immature & Ovary: clear, thread-like, pink in colour & Previtellogenic oocytes present \\
\hline II & Regressed & Ovary: small, clear and pink in colour & Cortical alveoli stage oocytes present \\
\hline III & Vitellogenic & $\begin{array}{l}\text { Ovary: colour orange, opaque oocytes } \\
\text { visible through epithelium }\end{array}$ & Oocytes in exogenous vitellogenesis \\
\hline IV & Hydrated & $\begin{array}{l}\text { Ovary: hydrated oocytes visible through } \\
\text { epithelium }\end{array}$ & $\begin{array}{l}\text { Final oocyte maturation, hydrated } \\
\text { oocytes present }\end{array}$ \\
\hline V & Ovulated & $\begin{array}{l}\text { Eggs: in the oviduct and can be extruded } \\
\text { with gentle pressure }\end{array}$ & $\begin{array}{l}\text { Hydrated oocytes and post-ovulatory } \\
\text { follicles present }\end{array}$ \\
\hline VI & Spent & Ovary: bloody and flaccid & $\begin{array}{l}\text { Atretic vitellogenic oocytes and previtello- } \\
\text { genic oocytes present }\end{array}$ \\
\hline \multicolumn{4}{|l|}{ Male } \\
\hline I & Immature & Testis: white, thread-like & Spermatogonia \\
\hline II & Spermatogenic & Testis: firm and ivory white in colour & $\begin{array}{l}\text { Secondary spermatocytes and spermatozoa } \\
\text { present }\end{array}$ \\
\hline III & Partially spermiated & $\begin{array}{l}\text { Testis: firm, ivory white in colour with } \\
\text { viscous milt in sperm duct }\end{array}$ & Spermatozoa predominate \\
\hline IV & Fully spermiated & $\begin{array}{l}\text { Testis: firm, ivory white in colour with } \\
\text { free-flowing milt in sperm duct }\end{array}$ & Spermatozoa predominate \\
\hline V & Spent & Testis: grey to bloody in colour and flaccid & $\begin{array}{l}\text { Residual spermatozoa, reduced spermato- } \\
\text { cytes and increased connective tissue }\end{array}$ \\
\hline
\end{tabular}

\section{Mode of spawning and batch fecundity}

Gonad tissue from a subset of females was preserved in a solution of formaldehyde, acetic acid and calcium carbonate to determine the mode of spawning and estimate potential batch fecundity. The patterns of oocyte development and mode of spawning were determined by examining the oocyte diameters of 5 individuals with Stage III ovaries and 5 individuals with Stage IV ovaries collected in the Tuross River during the identified spawning period. Each ovary was blotted dry and weighed (within $0.0001 \mathrm{~g}$ ), after which 3 replicate sub-samples were taken, blotted dry, weighed (within $0.0001 \mathrm{~g}$ ) and placed in a sealed sample jar containing a $70 \%$ alcohol solution. Each sub-sample was then placed in a sonic bath (Unisonics FXP4) for a period no longer than 20 min to dislodge individual oocytes from surrounding connective tissue. Oocytes from each sub-sample were transferred into a Petri dish and separated from each other, with all remaining connective tissue removed. The Petri dish was scanned (Canon CanoScan 8600F) at 1200 dpi resolution, and image analysis software (ImageJ Version 1.381) was used to determine the size and number of oocytes in each sub-sample. Individual size-frequency plots of oocyte diameters were produced for each of the 2 gonad stages.
Estimates of potential batch fecundity were determined by counting the number of hydrated eggs present within Stage IV ovaries from individuals ranging in size from 290 to $420 \mathrm{~mm}$ FL collected from the Tuross River during the identified spawning period. The number of hydrated eggs in a weighed $(\sim 0.1 \mathrm{~g})$ subsample of ovarian tissue was counted, and the potential total batch fecundity for each fish was estimated by scaling this number up to the total gonad weight. A linear regression analysis was used to determine the significance of the relationship between estimated potential batch fecundity and FL.

\section{Length and age at maturity}

The estimated FL and age at which $50 \%\left(L_{50}\right.$ and $A_{50}$ respectively) of males and females attained reproductive maturity in the Tuross River was determined in each case by fitting a logistic regression model using the binomial general linear model function in the R statistical environment to the proportions of mature (Stage III and above) and immature (Stage I and II) fish in each $1 \mathrm{~cm}$ length class and each age class. No useful estimates of $L_{50}$ and $A_{50}$ could be derived for fish collected in the Clarence River because of a lack of immature fish sampled 
and, for Tuggerah Lake, because of a lack of mature fish sampled. Only fish caught during the identified spawning period were used for these analyses, and differences between sexes in the estimated $L_{50}$ and $A_{50}$ values in the Tuross River were tested using the 2-sampled $Z$ technique (Gunderson 1977).

\section{Age estimation: otoliths and scales}

Discrepancies exist in estimates of growth and longevity for Girella tricuspidata; previous work provided vastly different maximum ages, but these differences were most likely attributable to the structures (scales versus otoliths) used for ageing (Gray et al. 2010). We tested this hypothesis by using both sectioned sagittal otoliths and whole scales to estimate the age of G. tricuspidata. Otoliths from each fish were cleaned and dried, and one was embedded in resin, after which a $300 \mu \mathrm{m}$ transverse section was made through the core perpendicular to the longest axis. Scales were cleaned, dried and briefly examined to select the most readable scale from each fish for further examination. When no interpretable scales were collected (i.e. they had regenerated or were deformed; a total of 113 fish), those fish were excluded from further analyses. Whole scales and otolith sections were mounted on slides and viewed using a microscope with reflected white light against a black background. The scales and otolith sections displayed alternating narrow opaque and broad translucent zones, and the numbers of completed opaque zones along a radius from the core to the outer edge of the structure were counted. All structures were read without knowledge of sample details (i.e. length, sex, location and date of capture), and $25 \%$ of otoliths haphazardly drawn from each estuary and $25 \%$ of scales from the Tuross River were reread by the same reader. The repeatability of counts of opaque zones (combined across all age classes and samples) was assessed using the coefficient of variation (CV) (Campana 2001). Age bias plots were used to determine whether there was systematic variation in the estimated ages of individual G. tricuspidata in the Tuross River derived from sectioned otoliths and whole scales (Campana et al. 1995).

\section{Identification of first opaque zone on otoliths}

The position and timing of deposition of the first opaque zone on otoliths were determined by keeping young-of-the-year fish in an aquarium facility. A total of 25 juveniles (20 to $80 \mathrm{~mm}$ FL) were captured in Botany Bay $\left(34.02^{\circ} \mathrm{S}, 151.32^{\circ} \mathrm{E}\right)$ in March 2005 , transferred and housed in a $5000 \mathrm{l}$ tank at the nearby Cronulla Fisheries Research Centre $\left(34.17^{\circ} \mathrm{S}, 151.35^{\circ} \mathrm{E}\right)$. Fish were collected from Botany Bay due to its closeness to the research facility to minimise the logistic constraints of transporting fish from distant locations. It was not possible to replicate the environmental conditions from each of the 3 study estuaries in the laboratory. Fish were therefore maintained at local ambient water and air temperatures (water pumped directly from the Port Hacking estuary), exposed to natural cycles of light and fed commercially available pellets (Ridley Aqua Feed) once a day. Every 3 mo between September 2005 and December 2006, 5 fish were captured, euthanised and had their otoliths removed. One otolith from each pair was processed for age estimation as described above. The distance from the otolith core to the otolith edge and to the first opaque zone was measured using a microscope-mounted camera interfaced with digital image analysis software (ImageJ Version 1.381). All measurements were made along the ventral margin of the sulcus acusticus.

\section{Growth}

Growth was modelled separately for each sex in each estuary by fitting the von Bertalanffy growth function (VBGF) to the length-at-age data from sectioned otoliths. Because of variations in the proportions of small and young fish obtained in samples (Table 2), the analyses for the Clarence River and Tuggerah Lake were constrained with $t_{0}=-0.3$. This was based on unconstrained results from the Tuross River, which had the widest spread of size and age groups in samples (Table 2). The best-fit VBGF for each sex in each estuary was determined using nonlinear least-squares procedures, and the growth curves between sexes and among estuaries were compared using likelihood ratio (LR) tests (Kimura 1980, Cerrato 1990).

\section{Population connectivity}

Between 1988 and 1995, Girella tricuspidata in 9 estuaries in NSW were captured in beach-seine nets, measured (FL to the nearest $\mathrm{cm}$ ), tagged with a unique numbered plastic T-bar (Hallprint TBA) between the dorsal fin rays and released in situ. A total of 6871 G. tricuspidata were tagged, and their FL ranged between $127 \mathrm{~mm}$ and $562 \mathrm{~mm}$ (mean \pm 
Table 2. Girella tricuspidata. Abundance of males (M) and females (F) in each estimated age class in Clarence River, Tuggerah Lake and Tuross River throughout the study

\begin{tabular}{|c|c|c|c|c|c|c|}
\hline \multirow{2}{*}{$\begin{array}{l}\text { Age } \\
\text { (yr) }\end{array}$} & \multicolumn{2}{|c|}{ Clarence } & \multicolumn{2}{|c|}{ Tuggerah } & \multicolumn{2}{|c|}{ Tuross } \\
\hline & $\mathrm{M}$ & $\mathrm{F}$ & $\mathrm{M}$ & $\mathrm{F}$ & $\mathrm{M}$ & $\mathrm{F}$ \\
\hline 0 & 0 & 0 & 0 & 0 & 25 & 25 \\
\hline 1 & 1 & 1 & 24 & 22 & 77 & 79 \\
\hline 2 & 8 & 5 & 67 & 57 & 49 & 67 \\
\hline 3 & 28 & 33 & 78 & 75 & 18 & 48 \\
\hline 4 & 47 & 34 & 87 & 71 & 50 & 74 \\
\hline 5 & 30 & 21 & 61 & 64 & 51 & 92 \\
\hline 6 & 22 & 25 & 36 & 51 & 50 & 76 \\
\hline 7 & 21 & 27 & 23 & 35 & 34 & 63 \\
\hline 8 & 13 & 12 & 16 & 18 & 21 & 43 \\
\hline 9 & 2 & 2 & 5 & 7 & 12 & 18 \\
\hline 10 & 1 & 2 & 8 & 2 & 10 & 7 \\
\hline 11 & 0 & 3 & 1 & 2 & 6 & 8 \\
\hline 12 & 1 & 1 & 2 & 1 & 5 & 3 \\
\hline 13 & 0 & 0 & 1 & 1 & 3 & 3 \\
\hline 14 & 0 & 0 & 2 & 1 & 7 & 5 \\
\hline 15 & 1 & 0 & 1 & 1 & 8 & 5 \\
\hline 16 & 0 & 0 & 1 & 1 & 2 & 1 \\
\hline 17 & 0 & 2 & 1 & 0 & 4 & 2 \\
\hline 18 & 0 & 1 & 1 & 1 & 1 & 2 \\
\hline 19 & 0 & 0 & 1 & 0 & 0 & 0 \\
\hline 20 & 0 & 0 & 0 & 0 & 0 & 0 \\
\hline 21 & 0 & 0 & 0 & 0 & 0 & 0 \\
\hline 22 & 0 & 0 & 0 & 0 & 0 & 0 \\
\hline 23 & 0 & 0 & 0 & 0 & 0 & 0 \\
\hline 24 & 0 & 0 & 0 & 0 & 0 & 1 \\
\hline Total & 175 & 169 & 416 & 410 & 433 & 622 \\
\hline
\end{tabular}

standard error [SE]: $260.1 \pm 0.46 \mathrm{~mm}$ ). Tagging took place year-round in association with commercial fishers, so the time of tagging in a particular estuary was often dependent on the fisher's activity. The tagrelease program was highly publicised, with fishers offered a reward upon the return of tagged fish and supply of information including where and when the fish was recaptured and, where applicable, rereleased. A $\chi^{2}$ goodness-of-fit test was used to determine whether there was a significant difference in the numbers of fish that relocated north or south. Because only 4 fish relocated south, meaningful statistical analyses comparing the distances relocated either north or south could not be conducted. The extent of movements between the points of release and subsequent capture were plotted on a map.

\section{RESULTS}

\section{Reproductive period}

Mean male and female GSI peaked between June and September in the Clarence River but between October and January (and in February 2005) in the
Tuross River (Fig. 1). In contrast, the mean GSI values changed little throughout the year for each sex in Tuggerah Lake, although slightly higher mean GSI values were evident in August and September 2003 and in July and November 2004 (Fig. 1). The greatest mean GSI for females was 8.62 in the Clarence River and 7.18 in the Tuross River, but only 1.83 in Tuggerah Lake. Based on the macroscopic staging of gonads, the greatest proportion of mature female and male fish (Stage III to Stage VI) occurred between May and September in the Clarence River and between October and March in the Tuross River (Fig. 2). No Stage V males occurred in samples. Very few reproductively active fish were sampled in Tuggerah Lake in any month, precluding the identification of any temporal reproductive pattern.

\section{Mode of spawning and batch fecundity}

The frequency distribution of oocyte diameters differed between individuals with Stage III ovaries and those with Stage IV ovaries (Fig. 3). The diameters of the largest cohort of oocytes ranged between 0.40 and $0.55 \mathrm{~mm}$ for individuals with Stage III ovaries and between 0.60 and $0.75 \mathrm{~mm}$ for those with Stage IV

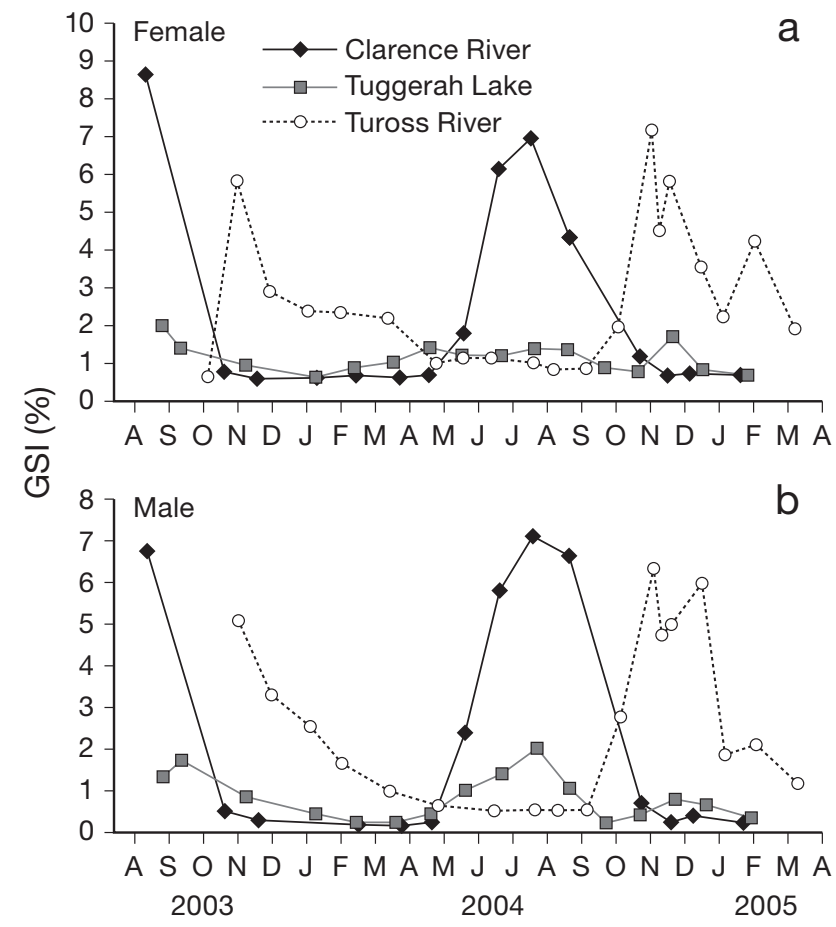

Fig. 1. Girella tricuspidata. Mean gonadosomatic indices (GSI) for (a) females and (b) males in Clarence River, Tuggerah Lake and Tuross River 

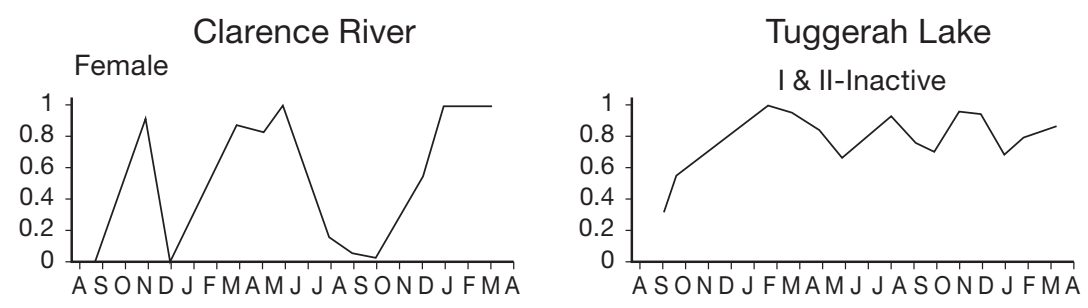

Tuross River
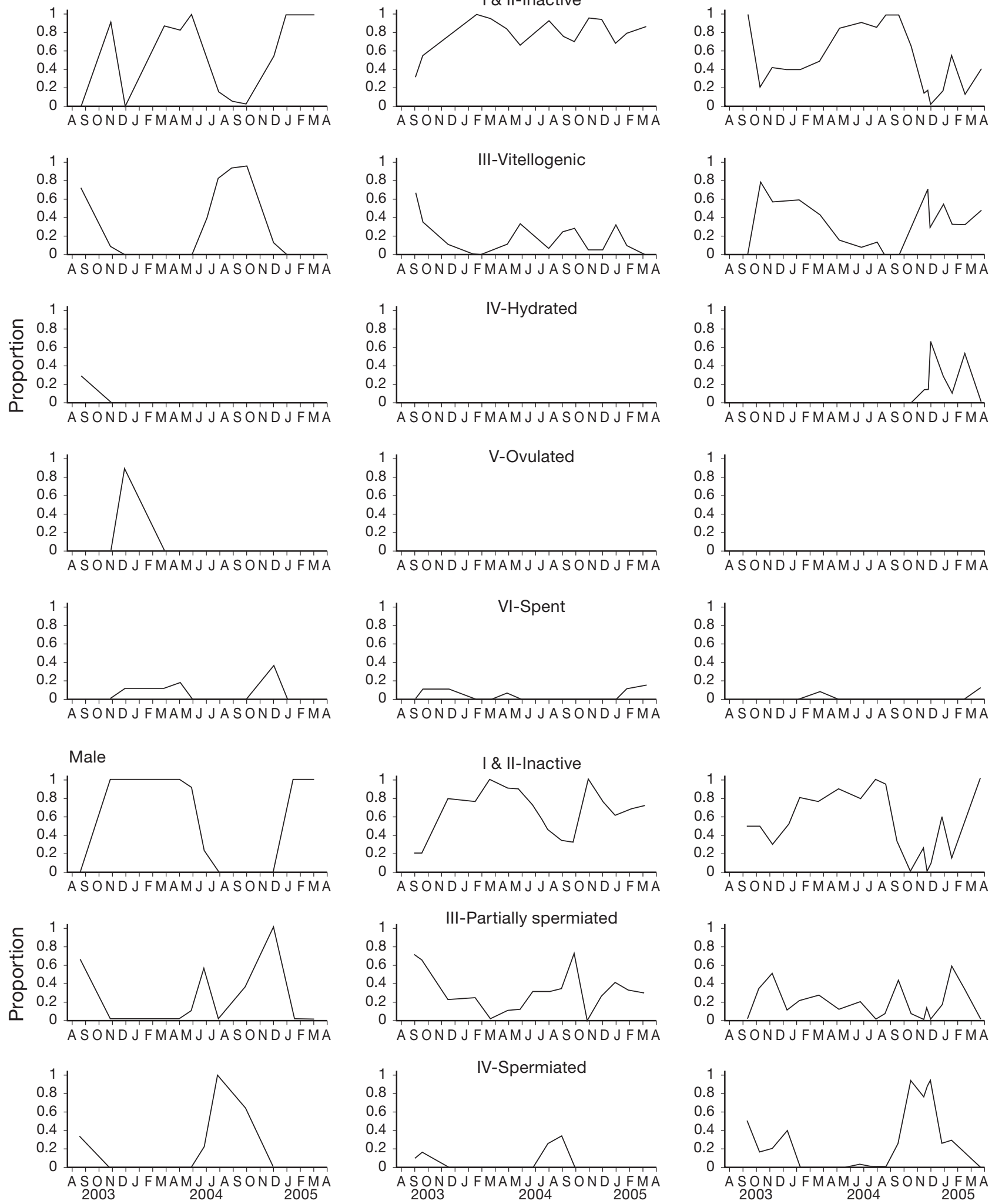

Fig. 2. Girella tricuspidata. Proportion of each assigned gonad stage (see Table 1) for females and males in Clarence River, Tuggerah Lake and Tuross River 
ovaries. A cohort of oocytes with diameters of 0.40 to $0.55 \mathrm{~mm}$ was also obvious in some individuals with Stage IV ovaries (e.g. Fig. 3d,e). For Stage III and IV gonads, there was a scattering of developing oocytes with diameters ranging from 0.20 to $0.40 \mathrm{~mm}$ (Fig. 3). The frequency distribution of oocyte diameters within mature ovaries is indicative of asynchronous oocyte development, which is consistent with batch spawning.

Estimates of potential batch fecundity ranged between 64 000 and 834000 eggs for Girella tricuspidata between 296 and $426 \mathrm{~mm}$ FL (495 to $1312 \mathrm{~g}$ total weight) respectively (Fig. 4). There was a significant positive relationship between the relative batch fecundity and FL ( $\left.\mathrm{p}=0.00057, \mathrm{r}^{2}=0.2215\right)$.

\section{Length and age at maturity}

The smallest observed mature female and male in the Tuross River were $273 \mathrm{~mm}$ and $264 \mathrm{~mm}$ FL respectively, whereas the estimated $L_{50}$ and $A_{50}( \pm \mathrm{SE})$ were $294.6 \pm 4.0 \mathrm{~mm}(\mathrm{n}=418)$ and $4.52 \pm 0.1 \mathrm{yr}(\mathrm{n}=412)$ for females and $286.2 \pm 6.7 \mathrm{~mm}(\mathrm{n}=242)$ and $4.16 \pm 0.2 \mathrm{yr}$
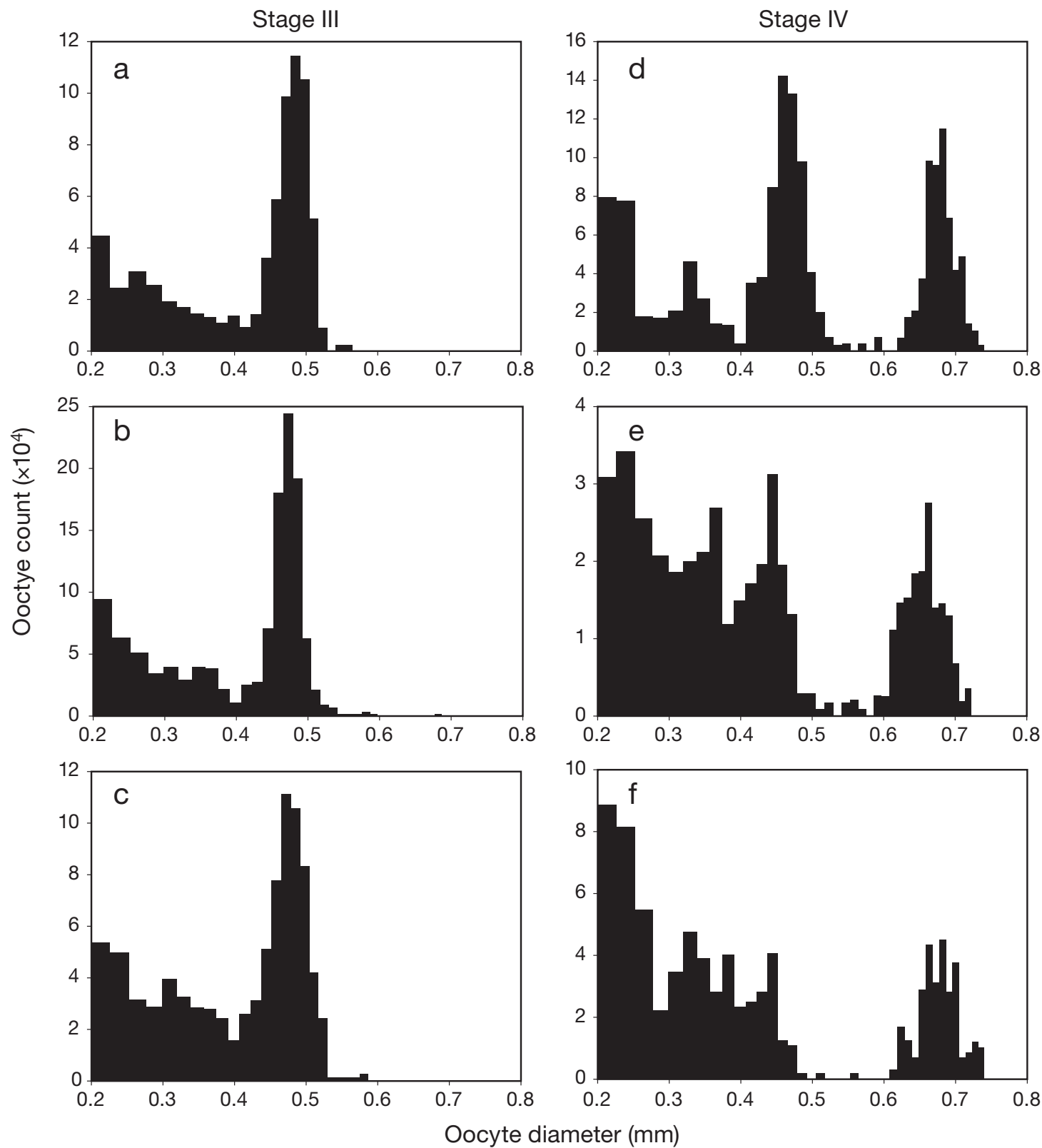

Fig. 3. Girella tricuspidata. Oocyte size frequency distributions within (a,b,c) 3 Stage III and (d,e,f) 3 Stage IV gonads of individuals sampled in Tuross River 


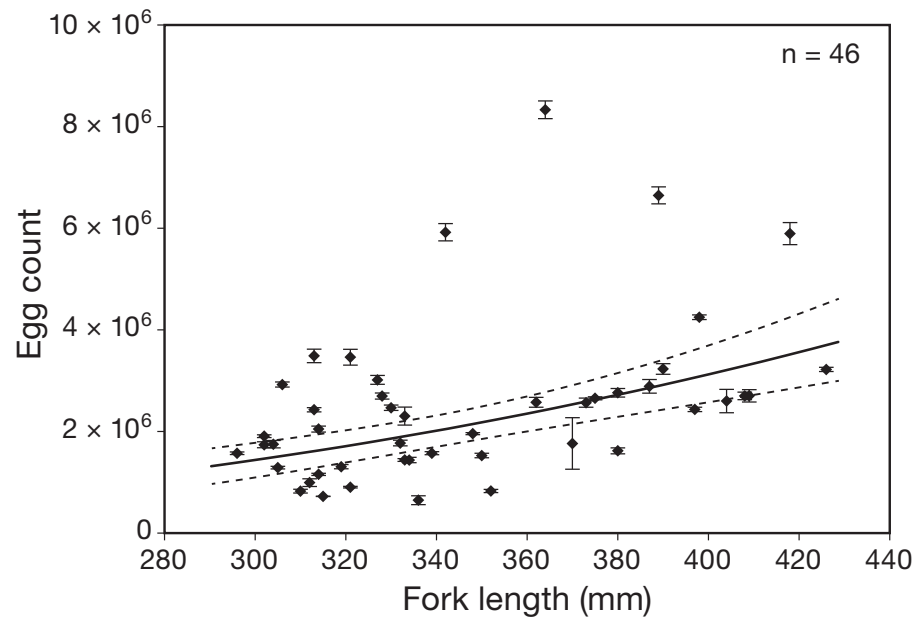

Fig. 4. Girella tricuspidata. Relationships between potential batch fecundity and fork length $( \pm \mathrm{SE})$ for individuals sampled in Tuross River. Analysis based on fish with Stage IV ovaries with hydrated oocytes

( $\mathrm{n}=237$ ) for males (Fig. 5). These estimates did not differ significantly (length, $\mathrm{p}=0.1419$; age, $\mathrm{p}=0.0975$ ) between sexes. The smallest observed mature female and male in the Clarence River were $222 \mathrm{~mm}$ and $191 \mathrm{~mm}$ FL, respectively, and in Tuggerah Lake were $275 \mathrm{~mm}$ and $267 \mathrm{~mm} \mathrm{FL}$, respectively.

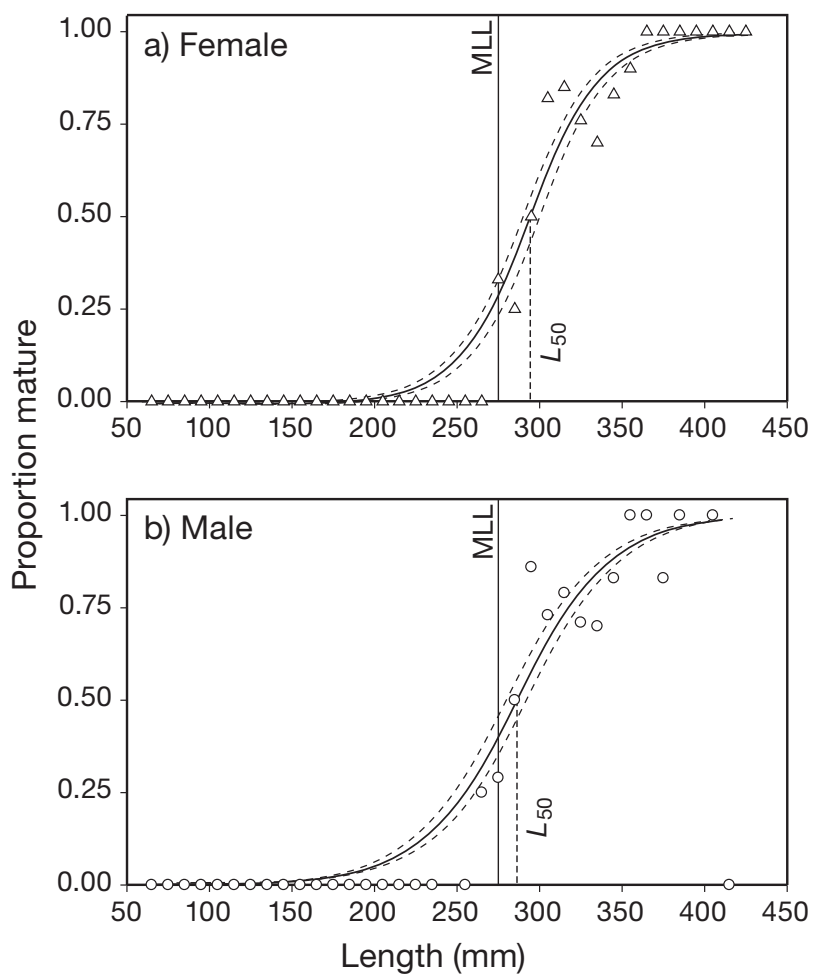

\section{Precision of age estimation and comparisons between otolith and scale readings}

The within-reader agreement for counting opaque zones on sectioned otoliths was $93.4 \%$, with a corresponding $\mathrm{CV}$ value of 10.6. The within-reader variation for scale interpretation was $90.1 \%(\mathrm{CV}=12.8)$.

The age-bias plots of the comparison of the counts of completed opaque zones on otoliths and scales showed similar values for fish aged $\leq 5 \mathrm{yr}$, after which the agreement between counts decreased because there was a systematic underestimation of ageing based on scales (Fig. 6). The maximum discrepancy between counts of opaque zones on otoliths and scales was 13 zones, and this was for a fish with 17 opaque zones on the otolith (Fig. 6).

\section{Validation of first opaque zone formation on otoliths}

Juvenile fish held in captivity were first sampled in September 2005, with all 5 sampled fish displaying a newly deposited opaque zone on their otoliths (Fig. 7). No further opaque zones were observed in fish sampled between December 2005 and June
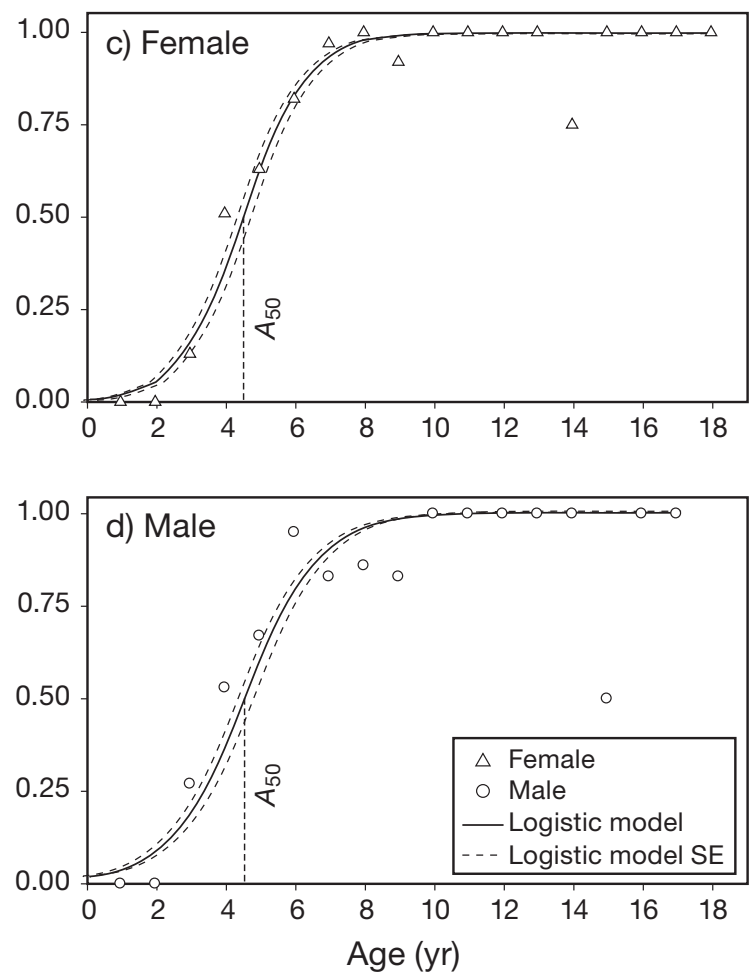

Fig. 5. Girella tricuspidata. Logistic curves showing $(\mathrm{a}, \mathrm{b})$ estimated fork length $\left(L_{50}\right)$ and $(\mathrm{c}, \mathrm{d})$ age $\left(A_{50}\right)$ at $50 \%$ sexual maturity for $(\mathrm{a}, \mathrm{c})$ females and $(\mathrm{b}, \mathrm{d})$ males sampled in Tuross River. MLL: minimum legal length of fish that can be retained 


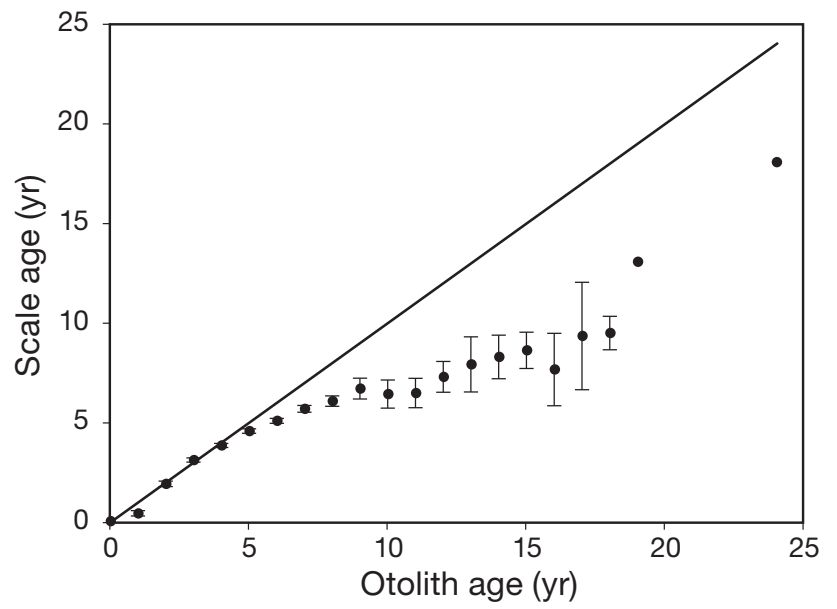

Fig. 6. Girella tricuspidata. Relationship between estimated ages of fish from sectioned otoliths and whole scales. Straight line shows 1:1 relationship; error bars represent $95 \%$ confidence limits $(n=1934)$

2006, whereas a second opaque zone was visible on the remaining 5 fish sampled in December 2006. These observations indicate that the first opaque zone was formed between July and September and the second between July and December. The mean $( \pm \mathrm{SE})$ distance from the otolith core to the first opaque zone of these captive fish was $0.361 \pm$ $0.008 \mathrm{~mm}$, whereas for wild-caught Girella tricuspidata $(\mathrm{n}=567)$, the distance was $0.373 \pm 0.005 \mathrm{~mm}$.

\section{Length-at-age and growth}

The length of Girella tricuspidata at any given age varied considerably within and among estuaries (Fig. 8). The oldest (and largest) fish sampled was a

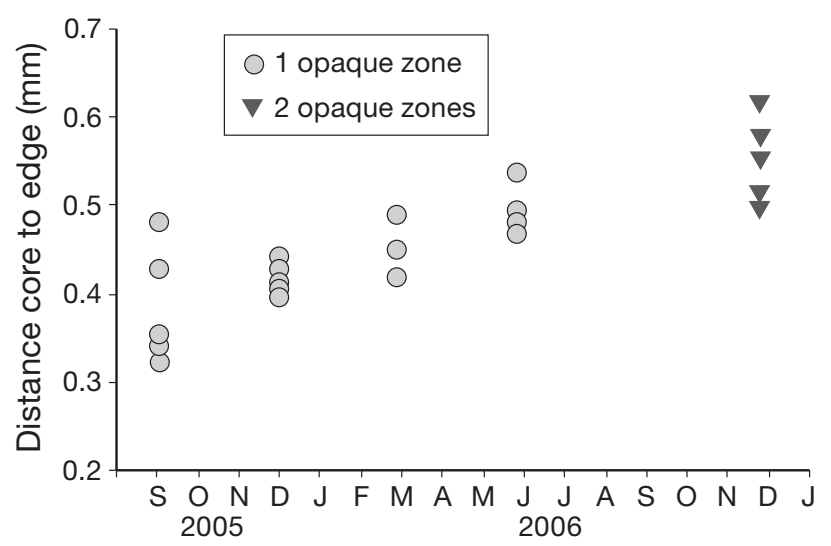

Fig. 7. Girella tricuspidata. Distances (mm) from the core to the edge of each otolith of juvenile fish kept in captivity and sampled at different times between September 2005 and December 2006
24 yr old female (426 mm FL) from the Tuross River. The oldest fish sampled in the Clarence River was a female aged $18 \mathrm{yr}$, and in Tuggerah Lake, the oldest fish was a male aged $19 \mathrm{yr}$. Few fish older than $10 \mathrm{yr}$ were sampled from all 3 estuaries (Table 2).

The von Bertalanffy growth curves differed significantly between males and females in the Clarence $(p<0.0001)$ and Tuross $(p=0.012)$ Rivers, where females grew faster and attained a greater mean estimated maximum length $\left(L_{\infty}\right)$ than males (Table 3,
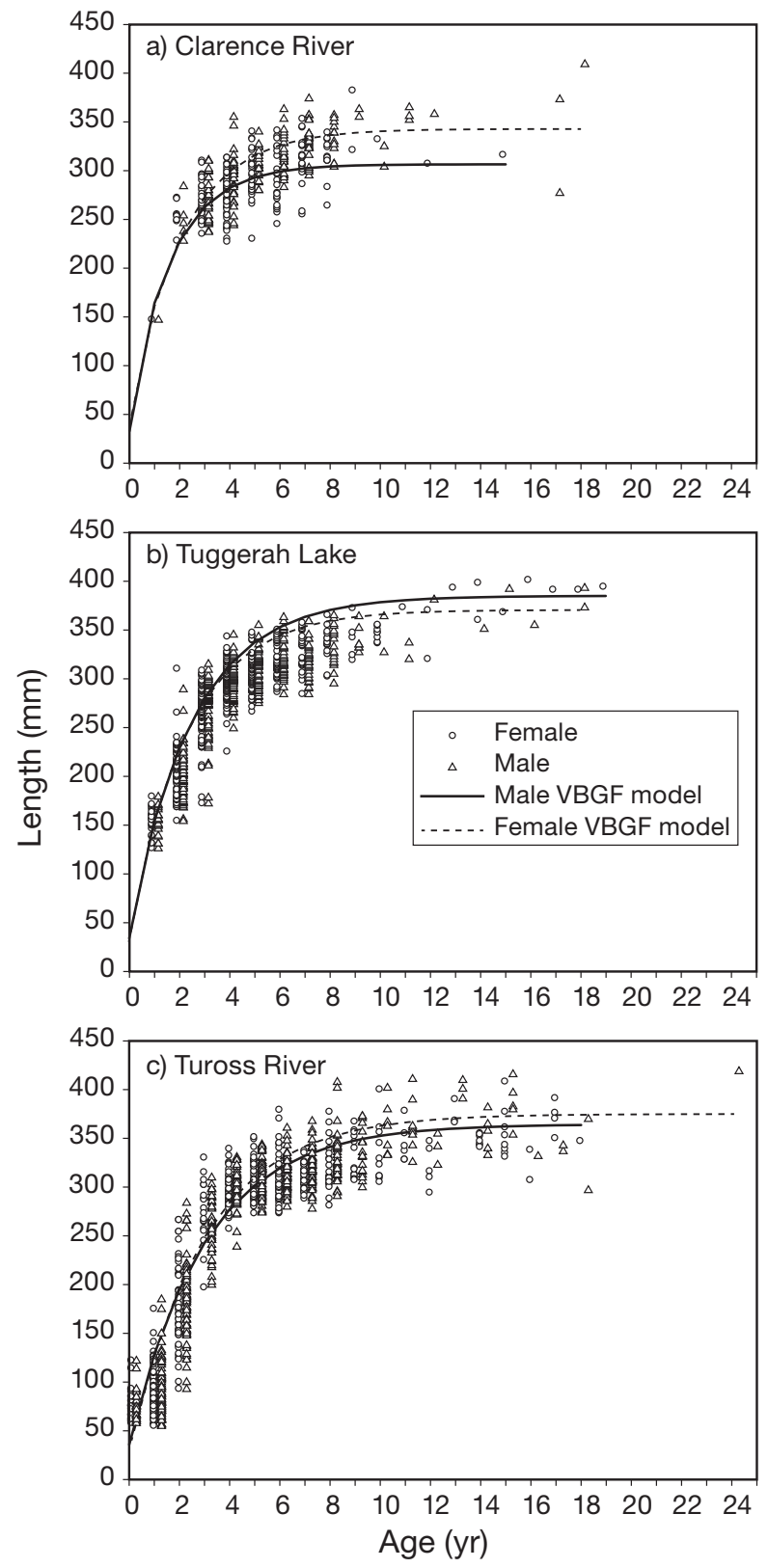

Fig. 8. Girella tricuspidata. Variation in fork length-at-age and von Bertalanffy growth curves for males and females in (a) Clarence River, (b) Tuggerah Lake and (c) Tuross River. Von Bertalanffy growth parameters are provided in Table 3 
Fig. 8). There was no significant difference $(p=$ $0.167)$ between the growth curves of males and females in Tuggerah Lake. The growth of Girella tricuspidata also differed significantly (in all cases, $\mathrm{p}<$ 0.05 ) among estuaries for fish of the same sex (Table 3, Fig. 8).

\section{Population connectivity}

Of the 6871 Girella tricuspidata tagged, 988 $(14.4 \%)$ were recaptured at least once. A total of 939 fish were recaptured once, 44 twice, 3 thrice, and two 4 times, providing a total of 1043 records of recapture (Table 4). The location of the first recapture was within the estuary in which the fish was tagged in all but 36 cases (including all 49 multiple-recapture fish), with the duration at large before the first recapture ranging between 1 and $1462 \mathrm{~d}$ (mean $\pm \mathrm{SE}=$ $125.9 \pm 3.9 d_{i} \mathrm{n}=988$ ) (Table 4). The direction along the coast that emigrating G. tricuspidata had relocated from the estuary in which they were tagged differed significantly $\left(H_{0}\right.$ : north $=$ south $; \chi^{2}=24.641$, $\mathrm{df}=1, \mathrm{p}<0.0001$ ) and was north in 35 cases and south in 4 cases (Fig. 9, Table 4). The distances relocated ranged between 11 and $455 \mathrm{~km}$ for northwardrelocated fish (mean $\pm \mathrm{SE}=160.2 \pm 21.2 \mathrm{~km} ; \mathrm{n}=35)$, with the furthest relocation being from the Shoalhaven River to the Hastings River. Southwardrelocated fish travelled between 26 and $78 \mathrm{~km}$ (mean $\pm \mathrm{SE}=46.3 \pm 11.1 \mathrm{~km} ; \mathrm{n}=4$ ), with the furthest relocation being from the Shoalhaven River to Lake Conjola (Fig. 9). The small number of southwardrelocated fish prevented meaningful analysis comparing distances moved between the 2 groups.

The mean $( \pm$ SE) duration at large before the first recapture for all recaptured Girella tricuspidata was $125.8 \pm 3.9 \mathrm{~d}(\mathrm{n}=986)$. Of the 49 multiple-recapture fish, 41 were tagged in estuaries on the north coast. For all but 2 of the multiple-recapture fish, the sec- ond and subsequent recaptures were, like the first, within the estuary in which the fish was initially tagged, with the cumulative duration at large prior to

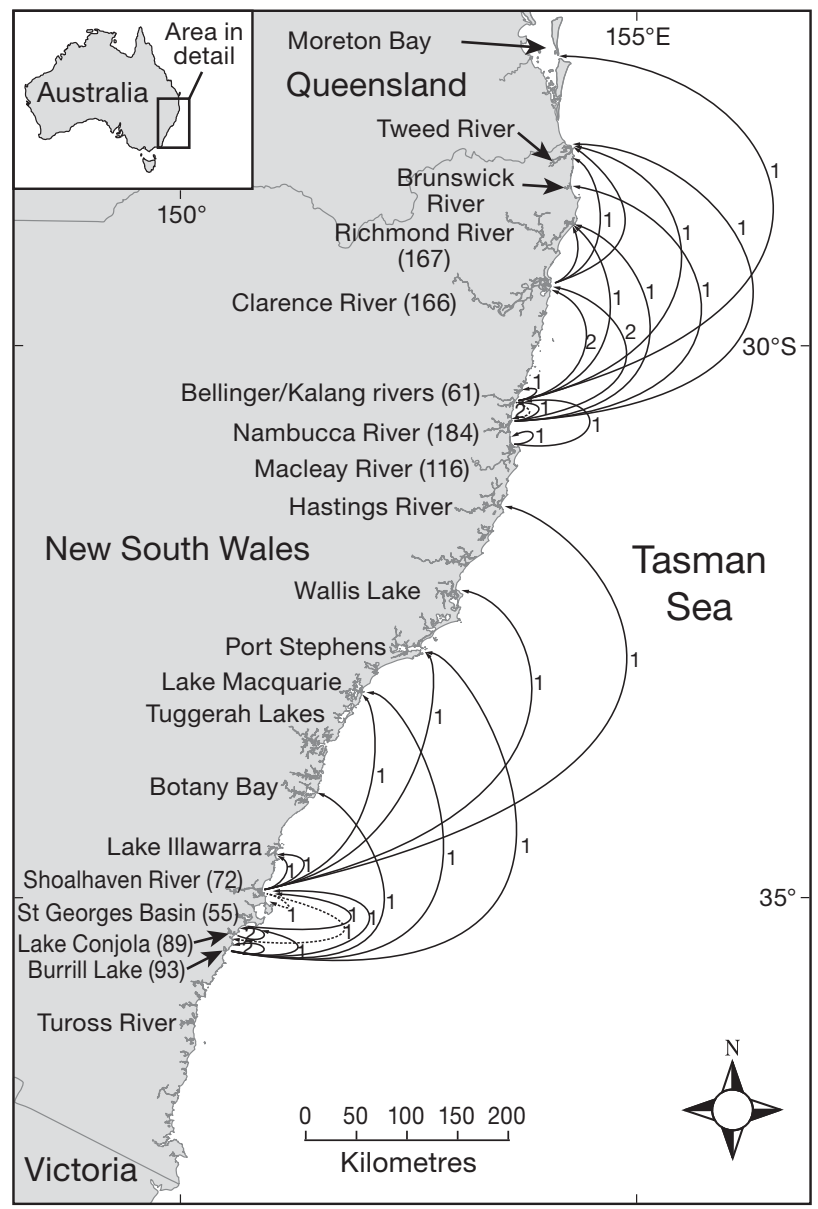

Fig. 9. Girella tricuspidata. Locations of released and recaptured fish tagged in estuaries throughout New South Wales. Number of fish movements northward (solid line) or southward (dashed line) is shown adjacent to each line. The numbers in parentheses associated with some estuary names represent the total number of all recaptures (i.e. single and multiple combined) of fish tagged and recaptured in that estuary

Table 3. Girella tricuspidata. Best fit Von Bertalanffy growth function (VBGF) parameters asymptotic length ( $\left.L_{\infty}\right), k$ and the constrained $t_{0}$ for male and female fish in Clarence River, Tuggerah Lake and Tuross River and results of the likelihood ratio (LR) tests comparing the VBGF between sexes and among estuaries. ns: $p>0.05{ }_{i}^{*} p<0.05_{i}{ }^{* * *} p<0.001$

\begin{tabular}{|c|c|c|c|c|c|c|c|c|}
\hline Group & Location & Sex & $L_{\infty}( \pm \mathrm{SE})$ & $k( \pm \mathrm{SE})$ & $t_{0}$ & RSS & $\mathrm{n}$ & LR test and significance \\
\hline 1 & Clarence & Male & $307.753(3.628)$ & $0.5935(0.36)$ & -0.3 & 104539.33 & 175 & 1 vs. $2^{* * *}, 1$ vs. $3^{* * *}, 1$ vs. $5^{* * *}$ \\
\hline 2 & Clarence & Female & $338.838(3.642)$ & $0.4786(0.021)$ & -0.3 & 82189.53 & 169 & 2 vs. $1^{* * *}, 2$ vs. $4^{* * *}, 2$ vs. $6^{* * *}$ \\
\hline 3 & Tuggerah & Male & $385.533(3.447)$ & $0.3944(0.01)$ & -0.3 & 256177.5 & 416 & 3 vs. $1^{* * *}, 3$ vs. $4^{\text {ns }}, 3$ vs. $5^{* * *}$ \\
\hline 4 & Tuggerah & Female & $375.025(3.156)$ & $0.4222(0.011)$ & -0.3 & 245584.08 & 410 & 4 vs. $2^{* * *}, 4$ vs. $3^{\text {ns }}, 4$ vs. $6^{* * *}$ \\
\hline 5 & Tuross & Male & $363.03(4.11)$ & $0.3309(0.01)$ & -0.3 & 482169.34 & 434 & 5 vs. $1^{* * *}, 5$ vs. $3^{* * *}, 5$ vs. $6^{* * *}$ \\
\hline 6 & Tuross & Female & $370.41(3.44)$ & $0.3351(0.009)$ & -0.3 & 585605.89 & 622 & 6 vs. $2^{* * *}, 6$ vs. $4^{* * *}, 6$ vs. $5^{*}$ \\
\hline
\end{tabular}




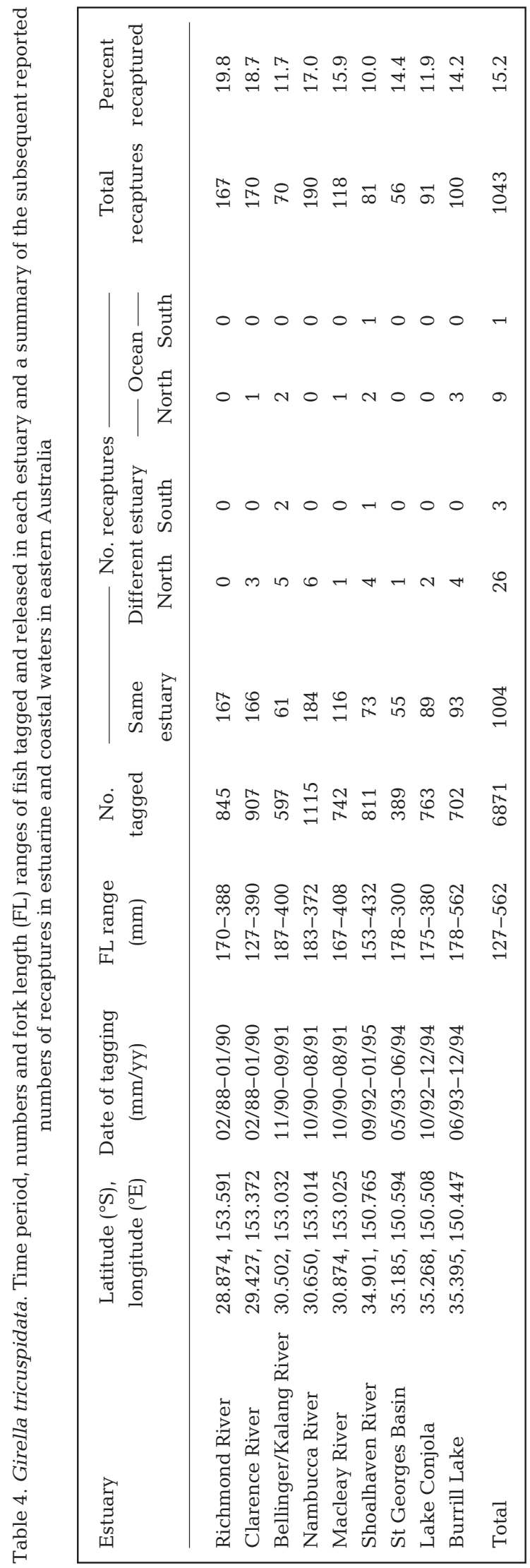

the second recapture ranging between 18 and $392 \mathrm{~d}$ $($ mean $\pm \mathrm{SE}=169.8 \pm 14.0 \mathrm{~d} ; \mathrm{n}=49)($ Table 4$)$. The 2 exceptions were a fish initially tagged in Lake Conjola and recaptured the second time $(31 \mathrm{~d}$ after initially being tagged) in St Georges Basin $(27 \mathrm{~km}$ north) and a fish tagged in the Nambucca River and recaptured a second time (130 d after initially being tagged) in the Clarence River (152 km north). The mean $( \pm \mathrm{SE})$ cumulative duration at large prior to the third and fourth recaptures for the applicable multiple-recapture fish was $249.0 \pm 21.4 \mathrm{~d}(\mathrm{n}=5)$ and $292.0 \pm 13.0 \mathrm{~d}(\mathrm{n}=2)$ respectively, with only 1 of those 5 fish eventually leaving the estuary (Macleay River) in which it was tagged to be recaptured $\sim 50 \mathrm{~km}$ north in the Bellinger River.

\section{DISCUSSION}

\section{Reproduction}

Populations of Girella tricuspidata displayed protracted periods of reproductive activity that varied between the 2 most distant estuaries, occurring mainly between June to September (winter) in the Clarence River and October to January (spring/ summer) in the Tuross River. This suggests that spawning of G. tricuspidata potentially varies with latitude throughout eastern Australia, a pattern observed for other species, including Hyporhamphus australis (Hughes \& Stewart 2006) and Macquaria colonorum (Walsh et al. 2011). Latitudinal and longitudinal variations in the duration and timing of peak reproductive activity are common in species of fish that are widely distributed (Bye 1990, Fowler et al. 1999, Sarre \& Potter 1999, DeVries et al. 2002). We acknowledge, however, that because we only had samples from 2 distant estuaries, the patterns observed here might not be indicative of all estuaries within each region. Further sampling in other estuaries is required to determine the extent of variation in reproductive activity across the species distribution prior to any implementation of a management strategy that incorporates temporal fishing closures to protect spawning fish.

A consequence of the variable and protracted spawning period of Girella tricuspidata that occurs over at least 6 mo throughout the study area is that recruitment of young-of-the-year to inshore nursery grounds is spatially and temporally variable. For example, larval G. tricuspidata have been recorded in coastal waters adjacent to Sydney, central NSW, between August and May (Gray \& Miskiewicz 2000), 
and different cohorts of newly settled juveniles have been observed in seagrasses in the Sydney region between July and March (Smith \& Sinerchia 2004). Sampling of juveniles in seagrass beds in several estuaries throughout NSW identified that small postsettlement individuals $(<20 \mathrm{~mm}$ FL) were most predominant between July and November in northern NSW (Clarence and Sandon Rivers) but between July and April in southern NSW (Shoalhaven River and Sussex Inlet) (Gray et al. 2000). We hypothesise that the northern recruits originated from local northern spawning events, but the recruits captured in the southern estuaries originated from both distant northern spawnings (early season) and local spawnings (later season). This may explain why recruits of G. tricuspidata were observed in the southern estuaries prior to local (spring) spawning. Transportation of eggs and larvae from northern waters to southern waters is likely facilitated by the southward-flowing East Australian Current.

Girella tricuspidata with hydrated oocytes were captured only in the lower marine-dominated reaches of the Clarence and Tuross Rivers. Although no direct observations of spawning were made, these observations indicate that G. tricuspidata could potentially spawn in these areas. It is generally assumed that G. tricuspidata spawns in nearshore coastal waters adjacent to surf beaches and estuary mouths (Kailola et al. 1993), and we acknowledge that fish could swim out of these estuaries into coastal waters within a diel or tidal cycle prior to actual spawning (Walsh et al. 2011). Moreover, the actual spawning locations of $G$. tricuspidata could be flexible and vary depending on local hydrographic conditions at the time of spawning. This may prohibit the use of rigid spatial closures to protect spawning adults as a management strategy for this species.

The oocytes of Girella tricuspidata developed in an asynchronous pattern, with mature Stage IV fish exhibiting oocytes at varying stages of development. These data indicate that $G$. tricuspidata have an indeterminate fecundity and likely spawn multiple times during the spawning period (De Vlaming 1983, West 1990). This type of spawning behaviour is common among many species of fish and is a strategy that maximises egg production in a spawning period and can help buffer adverse biotic and abiotic conditions that may affect the survival of eggs and larvae (Lambert \& Ware 1984, Burt et al. 1988, Sarre \& Potter 1999, Kendall \& Gray 2009). We could not determine the frequency and number of actual spawning events by an individual throughout a spawning season. Hence, the total number of eggs that each indi- vidual produced in a spawning season, and therefore their total overall annual fecundity, could not be estimated within the present study. Nevertheless, the estimated batch fecundity was significantly related to fork length, indicating that reproductive output is potentially greater in larger individuals and that the total collective reproductive output of a population could be enhanced by having greater proportions of larger fish (Parker 1992).

The estimated mean length and age of Girella tricuspidata at reproductive maturity in the Tuross River was similar for males and females, 286 and $294 \mathrm{~mm}$ FL and age 4.1 and $4.5 \mathrm{yr}$ respectively. These mean lengths and ages at maturity corresponded to $\sim 50$ and $60 \%$ of the observed maximum lengths of males and females respectively and $17 \%$ of the observed maximum age of $G$. tricuspidata sampled. Although differences among estuaries in the $L_{50}$ and $A_{50}$ of G. tricuspidata could not be tested due to sample limitations, the smallest mature male and female were much smaller in the Clarence River than in the other 2 estuaries, indicating that length at maturity could potentially vary among distant estuaries, as observed in other species of fish (Sarre \& Potter 1999, Silberschneider et al. 2009). This must be examined in greater detail to advise on an appropriate MLL for the species; the current MLL of $250 \mathrm{~mm}$ FL in NSW might need to be increased to allow a greater proportion of fish to attain sexual maturity and contribute to spawning prior to harvesting.

\section{Ageing}

Interpretation of scales was more difficult and less precise compared to sectioned otoliths and consistently led to underestimations of the ages of Girella tricuspidata that were $>5 \mathrm{yr}$ old. These results concur with the general paradigm that, for most species of fish, sectioned otoliths provide a more accurate estimate of age than scales, particularly for larger and older individuals (Casselman 1990, Campana 2001). We therefore assume that the previous scale-based ageing of G. tricuspidata (Pollock 1981) underestimated the true ages of older fish. This most likely explains why the oldest fish examined here $(24 \mathrm{yr})$ and by Gray et al. (2010) (26 yr) was double the maximum age (12 yr) recorded by Pollock (1981). Underestimation of actual ages can have significant impacts on population dynamics modelling and fisheries assessments (Lai \& Gunderson 1987, Campana 2001).

The first opaque zone on the otoliths of captive young-of-the-year fish formed over the austral winter/ 
early spring, which is in general agreement with that observed in similar field- and aquaria-based validation studies of young-of-the year of other species of fish in southeastern Australia (Hughes et al. 2008, Kendall et al. 2009). Based on the assumption that the first opaque zone forms throughout winter/spring across all estuaries, we hypothesise that the age of Girella tricuspidata when the first opaque zone is formed may vary among individuals according to location (i.e. latitude) along eastern Australia. For individuals spawned in winter (e.g. Clarence River), we predict they will be 12 to 15 mo old, whereas individuals born in spring and summer (e.g. Tuross River) may be only 9 to 12 mo old, when the first opaque zone forms the following winter/spring. Geographic variation in the age of fish when the first opaque zone is formed is common for species distributed over a wide geographic range (Fowler \& Short 1996). Future age validation studies of fish that are widely distributed need to account for such potential geographic variations in growth zone deposition. Ideally, validation studies should be based on more than one spawning cohort, and both field- and aquarium-based procedures should concurrently follow wild-caught and captive fish in different geographic places and years.

The general austral summer-to-autumn timing of completion of consequent opaque zones on otoliths of Girella tricuspidata (Gray et al. 2010) is similar to some species (e.g. Liza argentea; Kendall et al. 2009), but slightly later in the year than observed for other species (e.g. Rhabdosargus sarba; Hughes et al. 2008) in southeastern Australia. Differences in the timing of otolith deposition could be related to differences in the physiology and biochemistry among species (Campana 2001). Alternatively, it could also be a function of variability in the difficulty of interpreting completed growth zones on otoliths among species.

\section{Growth}

The growth of male and female Girella tricuspidata was relatively rapid until $\sim 4$ to $5 \mathrm{yr}$ of age, after which it slowed, a result consistent with that described by Gray et al. (2010). The age at which growth slows corresponds to the age that G. tricuspidata attain sexual maturity, which is a common trait among teleosts (Sarre \& Potter 2000, Walsh et al. 2010).

Differences in growth between sexes were not consistent among estuaries, a phenomenon that has been observed previously for Girella tricuspidata (Gray et al. 2010). Females had a faster rate of growth $(k)$ than males in all estuaries and attained a larger estimated asymptotic length in the Clarence and Tuross Rivers but not in Tuggerah Lake. Gray et al. (2010) previously observed that females grew faster and attained a larger length than males in the Clarence River but not in other studied estuaries. The combined results from these 2 studies highlight the plasticity in the growth characteristics of G. tricuspidata in eastern Australia. Inter-estuary and geographic variation in growth is common among fish species and can be dependent on a plethora of biotic and abiotic factors (Sarre \& Potter 2000, Bedee et al. 2002, Sala-Bozano \& Mariani 2011, Stocks et al. 2011). Such observed variations in growth parameters among populations could, however, simply reflect sample differences between sexes and among estuaries (Sainsbury 1980, Kritzer et al. 2001).

The observed wide range of lengths within each age class in each estuary is probably a manifestation of a combination of biotic and abiotic influences on the composition of populations. For example, each age class within an estuary could contain different cohorts of fish spawned several months apart as a result of the dispersal of eggs and larvae from local and distant spawning events. In addition, interspersion of individuals among meta-populations and genetic variation coupled with spatial and temporal differences in food availability and environmental conditions all potentially influence the observed variability in the length-at-age and growth of individuals (Blanck \& Lamouroux 2007, Searcy et al. 2007, Hoxmeier et al. 2009). The consequence of such length-at-age variation could potentially mask or lead to distortions of estuary-specific differences in the growth characteristics of Girella tricuspidata and other species.

\section{Population connectivity}

The tag-recapture data presented here and by Thomson (1959) show that Girella tricuspidata are capable of moving between distant estuaries (up to $450 \mathrm{~km}$ ) and that these movements are predominantly in a northerly direction. These movements, along with the potential relocation of eggs and larvae southwards via the East Australian Current, suggest that there is considerable population mixing of G. tricuspidata along eastern Australia. Although many individuals were recaptured in the same estuary in which they were tagged, the majority of these recaptures were within a short time period and may not indicate permanent residency. Novel acoustic tags have since been used successfully to determine the site fidelity and residency of fish in estuaries (Taylor 
et al. 2006, Heupel et al. 2010, Walsh et al. 2012), and similar studies are required to determine such attributes for G. tricuspidata.

Some movements of Girella tricuspidata between estuaries and coastal waters may be related to spawning. Throughout late autumn and winter, large schools of G. tricuspidata are often observed to congregate (presumably to spawn) near estuary mouths and coastal headlands and travel (mostly northward) along open surf beaches of central and northern NSW. During this period, G. tricuspidata are targeted and captured in large quantities by the coastal beach-seine fishery (Gray et al. 2000). The extent of the movements of these presumed 'spawning aggregations' has not been quantified and would require tracking individuals with more advanced acoustic telemetry technologies than used in the present study (e.g. Heupel \& Simpfendorfer 2008, Danylchuk et al. 2011). Nevertheless, we hypothesise that the predominant northerly movement displayed by $G$. tricuspidata, along with several other estuarine and coastal teleosts (Mugil cephalus, Acanthopagrus australis, Pagrus auratus and Pomatomus saltatrix) (Thomson 1959) and crustaceans (Penaeus plebejus) (Montgomery 1990) along the east Australian coast, is a life-history tactic to facilitate the wide dispersal of eggs and larvae by the southward-flowing East Australian Current to coastal and estuarine nursery areas. Essentially, fish move upstream into the prevailing current to spawn, after which eggs and larvae are transported and dispersed by longshore currents to nursery habitats, a tactic displayed by coastal fishes inhabiting other coastal boundary current systems (Hare \& Cowen 1993). Little is known, however, of the effects of the vagaries of the East Australian Current and associated oceanographic processes on rates of delivery and survival of larvae to inshore nursery grounds.

Acknowledgements. This study was funded by the NSW Government and the NSW Recreational Fishing Saltwater Trust. The sampling of wild populations and holding of experimental individuals in the aquaria was conducted under NSW Animal Ethics Permits 2002/20 and 2002/21. We particularly thank K. Gleed for field assistance and F. Ochwada and the anonymous referees for helpful comments on the manuscript.

\section{LITERATURE CITED}

Bedee CD, DeVries DA, Bortone SA, Palmer CL (2002) Estuary-specific age and growth of spotted seatrout in the northern Gulf of Mexico. In: Bortone SA (ed) Biology of spotted sea trout. CRC Press, Boca Raton, FL, p 57-77

Begg GA, Campana SE, Fowler AJ, Suthers IM (2005) Otolith research and application: current directions in innovation and implementation. Mar Freshw Res 56:477-483

- Blanck A, Lamouroux N (2007) Large-scale intraspecific variation in life history traits of European freshwater fish. J Biogeogr 34:862-875.

Burt A, Kramer DL, Nakatsuru K, Spry C (1988) The tempo of reproduction in Hyphessobrycon pulchripinnis (Characidae), with a discussion on the biology of 'multiple spawning' in fishes. Environ Biol Fishes 22:15-27

> Butcher PA, Broadhurst MK, Hall KC, Cooke SJ (2011) Postrelease survival and physiology of angled luderick (Girella tricuspidata) after confinement in keeper nets in an Australian estuary. ICES J Mar Sci 68:572-579

Bye VJ (1990) Temperate marine teleosts. In: Munro AD, Scott AP, Lam TJ (eds) Reproductive seasonality in teleosts: environmental influences. CRC Press, Boca Raton FL, p 125-144

Campana SE (2001) Accuracy, precision and quality control in age determination, including a review of the use and abuse of age validation methods. J Fish Biol 59:197-242

Campana SE, Annand MC, McMillan JI (1995) Graphical and statistical methods for determining the consistency of age-determination. Trans Am Fish Soc 124:131-138

Casselman JM (1990) Growth and relative size of calcified structures of fish. Trans Am Fish Soc 119:673-688

Cerrato RM (1990) Interpretable statistical tests for growth comparisons using parameters in the von Bertalanffy equation. Can J Fish Aquat Sci 47:1416-1426

Chateau O, Wantiez L (2009) Movement patterns of four coral reef fish species in a fragmented habitat in New Caledonia: implications for the design of marine protected area networks. ICES J Mar Sci 66:50-55

$>$ Danylchuk AJ, Cooke SJ, Goldberg TL, Suski CD and others (2011) Aggregations and offshore movements as indicators of spawning activity of bonefish (Albula vulpes) in the Bahamas. Mar Biol 158:1981-1999

De Vlaming VL (1983) Oocyte development patterns and hormonal involvements among teleosts. In: Rankin JC, Pitcher TJ, Duggan RT (eds) Control processes in fish physiology. Croom Helm, Beckenham, p 176-199

DeVries DA, Bedee CD, Palmer CL, Bortone SA (2002) The demographics and reproductive biology of spotted seatrout, Cynoscion nebulosus, in six northwest Florida estuaries. In: Bortone SA (ed) Biology of spotted sea trout. CRC Press, Boca Raton, FL, p 79-99

- Ebert TA, Hernandez JC, Russell MP (2011) Problems of the gonad index and what can be done: analysis of the purple sea urchin Strongylocentrotus purpuratus. Mar Biol 158:47-58

Fowler AJ, Short DA (1996) Temporal variation in the early life-history characteristics of the King George whiting Sillaginodes punctata from analysis of otolith microstructure. Mar Freshw Res 47:809-818

Fowler AJ, McLeay L, Short DA (1999) Reproductive mode and spawning information based on gonad analysis for King George whiting (Percoidei: Sillaginidae) from South Australia. Mar Freshw Res 50:1-14

> Gray CA, Kennelly SJ (2003) Catch characteristics of the commercial beach-seine fisheries in two Australian barrier estuaries. Fish Res 63:405-422

> Gray CA, Miskiewicz AG (2000) Larval fish assemblages in south-east Australian coastal waters: seasonal and spatial structure. Estuar Coast Shelf Sci 50:549-570

Gray CA, Pease BC, Stringfellow SL, Raines LP, Rankin BK, Walford TR (2000) Sampling estuarine fish for stock as- 
sessment. NSW Fisheries Final Rep Ser No. 18, Cronulla Gray CA, Johnson DD, Broadhurst MK, Young DJ (2005) Seasonal, spatial and gear-related influences on relationships between retained and discarded catches in a multispecies gillnet fishery. Fish Res 75:56-72

Gray CA, Ives MC, Macbeth WG, Kendall BW (2010) Variation in growth, mortality, length and age compositions of harvested populations of the herbivorous fish, Girella tricuspidata. J Fish Biol 76:880-889

Gunderson DR (1977) Population biology of pacific ocean perch, Sebastes alutus, stocks in the Washington-Queen Charlotte sound region, and their response to fishing. Fish Bull 75:369-403

Hare JA, Cowen RK (1993) Ecological and evolutionary implications of the larval transport and reproductive strategy of bluefish Pomatomus saltatrix. Mar Ecol Prog Ser 98:1-16

Henry GW, Lyle JM (2003) The national recreational and indigenous fishing survey. Final report to the Fisheries Research and Development Corporation, Project 99/158. NSW Fisheries Final Rep Ser No. 40, Cronulla

> Heupel MR, Simpfendorfer CA (2008) Movements and distribution of young bull sharks Carcharhinus leucas in a variable estuarine environment. Aquat Biol 1:277-289

Heupel MR, Yeiser BG, Collins AG, Ortega L, Simpfendorfer CA (2010) Long-term presence and movement patterns of juvenile bull sharks, Carcharhinus leucas, in an estuarine river system. Mar Freshw Res 61:1-10

> Hoxmeier RJH, Aday DD, Wahl DH (2009) Examining interpopulation variation in bluegill growth rates and size structure: effects of harvest, maturation, and environmental variables. Trans Am Fish Soc 138:423-432

> Hughes JM, Stewart J (2006) Reproductive biology of three commercially important hemiramphid species in southeastern Australia. Environ Biol Fishes 75:237-256

> Hughes JM, Stewart J, Kendall BW, Gray CA (2008) Growth and reproductive biology of tarwhine Rhabdosargus sarba (Sparidae) in eastern Australia. Mar Freshw Res 59:1111-1123

Jakobsen T, Fogarty MJ, Megrey BA, Moksness E (2009) Fish reproductive biology: implications for assessment and management. Wiley-Blackwell, Oxford

Kailola PJ, Williams MJ, Stewart PC, Reichelt RE, McNee A, Grieve C (1993) Australian fisheries resources. Bureau of Resource Science, Canberra

Kendall BW, Gray CA (2009) Reproduction, age and growth of Sillago maculata in south-eastern Australia. J Appl Ichthyol 25:529-536

Kendall BW, Gray CA, Bucher DD (2009) Age validation and variation in growth, mortality and population structure of Liza argentea and Myxus elongatus (Mugilidae) in two temperate Australian estuaries. J Fish Biol 75: 2788-2804

Kimura DK (1980) Likelihood methods for comparison of von Bertalanffy growth curves. Fish Bull 77:765-776

Kritzer JP, Davies CR, Mapstone BD (2001) Characterizing fish populations: effects of sample size and population structure on the precision of demographic parameter estimates. Can J Fish Aquat Sci 58:1557-1568

Lai HL, Gunderson DR (1987) Effects of ageing errors on estimates of growth, mortality and yield per recruit for walleye pollock (Theragra chalcogramma). Fish Res 5: 287-302

Lambert TC, Ware DM (1984) Reproductive strategies of demersal and pelagic spawning fish. Can J Fish Aquat Sci 41:1564-1569
Meekan MG, Ackerman JL, Wellington GM (2001) Demography and age structures of coral reef damselfishes in the tropical eastern Pacific Ocean. Mar Ecol Prog Ser 212:223-232

Megrey BA (1989) Review and comparison of the age-structured stock assessment models from the theoretical and applied points of view. Am Fish Soc Symp 6:8-48

> Meyer CG, Holland KN, Papastamatiou YP (2007) Seasonal and diel movements of giant trevally Caranx ignobilis at remote Hawaiian atolls: implications for the design of marine protected areas. Mar Ecol Prog Ser 333:13-25

Miskiewicz AG, Trnski T (1998) Girellidae: Blackfishes, luderick. In: Neira FJ, Miskiewicz AG, Trnski T (eds) Larvae of temperate Australian fishes. University of Western Australia Press, Perth, p 232-235

Montgomery SS (1990) Movements of juvenile eastern king prawns, Penaeus plebejus, and identification of stock along the east coast of Australia. Fish Res 9:189-208

Parker GA (1992) The evolution of sexual dimorphism in fish. J Fish Biol 41:1-20

Pollock BR (1981) Age determination and growth of luderick, Girella tricuspidata (Quoy and Gaimard), taken from Moreton Bay, Australia. J Fish Biol 19:475-485

Rowling KA, Hegarty A, Ives M (eds) (2010) Luderick. In: Status of fisheries resources in NSW 2008/09. Industry and Investment NSW, Cronulla, p 191-194

> Ruttenberg BI, Haupt AJ, Chiriboga AI, Warner RR (2005) Patterns, causes and consequences of regional variation in the ecology and life history of a reef fish. Oecologia 145:394-403

Sainsbury KJ (1980) Effect of individual variability on the von Bertalanffy growth equation. Can J Fish Aquat Sci 37:241-247

Sala-Bozano M, Mariani S (2011) Life history variation in a marine teleost across a heterogeneous seascape. Estuar Coast Shelf Sci 92:555-563

Sarre GA, Potter IC (1999) Comparison between the reproductive biology of black bream Acanthopagrus butcheri (Teleosti: Sparidae) in four estuaries with widely differing characteristics. Int J Salt Lake Res 8:179-210

Sarre GA, Potter IC (2000) Variation in age composition and growth rates of Acanthopagrus butcheri (Sparidae) among estuaries: some possible contributing factors. Fish Bull 98:785-799

Scott SG, Pankhurst NW (1992) Interannual variations in the reproductive cycle of the New Zealand snapper Pagrus auratus (Bloch \& Schneider) (Sparidae). J Fish Biol 41: 685-696

Searcy SP, Eggleston DB, Hare JA (2007) Is growth a reliable indicator of habitat quality and essential fish habitat for juvenile estuarine fish? Can J Fish Aquat Sci 64: 681-691

Silberschneider V, Gray CA, Stewart J (2009) Age, growth, maturity and the overfishing of the iconic sciaenid, Argyrosomus japonicus, in south-eastern Australia. Fish Res 95:220-229

Smith KA, Sinerchia M (2004) Timing of recruitment events, residence periods and post-settlement growth of juvenile fish in a seagrass nursery area, south-eastern Australia. Environ Biol Fishes 71:73-84

> Stocks J, Stewart J, Gray CA, West RJ (2011) Using otolith increment widths to infer spatial, temporal and gender variation in the growth of sand whiting Sillago ciliata. Fish Manag Ecol 18:121-131

> Taylor MD, Laffan SD, Fielder DS, Suthers IM (2006) Key 
habitat and home range of mulloway Argyrosomus japonicus in a south-east Australian estuary: finding the estuarine niche to optimise stocking. Mar Ecol Prog Ser 328:237-247

Thomson JM (1959) Some aspects of the ecology of Lake Macquarie, N.S.W., with regard to an alleged depletion of fish. X. The movements of fish. Aust J Mar Freshw Res 10:375-387

Walsh CT, Gray CA, West RJ, Van Der Meulen DE, Williams LFG (2010) Growth, episodic recruitment and age truncation in populations of a catadromous percichthyid, Macquaria colonorum. Mar Freshw Res 61:397-407

Walsh CT, Gray CA, West RJ, Williams LFG (2011) Reproductive biology and spawning strategy of the catadro-

Editorial responsibility: Benjamin Ruttenberg,

Palmetto Bay, Florida, USA mous percichthyid, Macquaria colonorum (Gunther, 1863). Environ Biol Fishes 91:471-486

- Walsh CT, Reinfelds IV, Gray CA, West RJ, van der Meulen DE, Craig JR (2012) Seasonal residency and movement patterns of two co-occurring catadromous percichthyids within a south-eastern Australian river. Ecol Freshw Fish 21:145-159

- West G (1990) Methods of assessing ovarian development in fishes: a review. Aust J Mar Freshw Res 41:199-222

West RJ, Gordon GNG (1994) Commercial and recreational harvest of fish from two Australian coastal rivers. Aust J Mar Freshw Res 45:1259-1279

Yagishita N, Nakabo T (2000) Review of the genus Girella (Girellidae) from East Asia. Ichthyol Res 47:119-135

Submitted: September 12, 2011; Accepted: March 9, 2012 Proofs received from author(s): June 4, 2012 